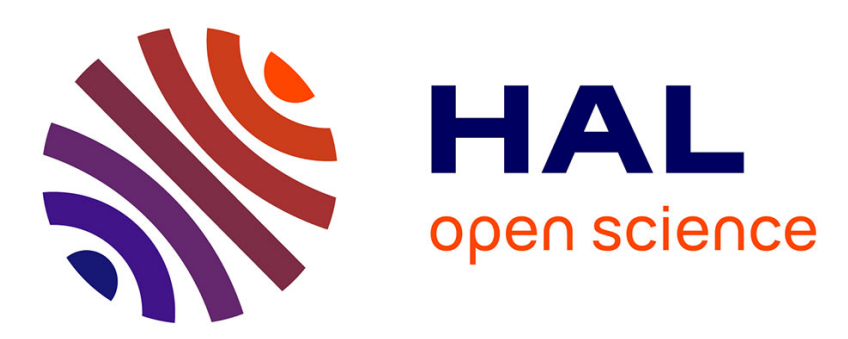

\title{
An optimized hair trap for non-invasive genetic studies of small cryptic mammals
}

Tobias Erik Reiners, Jorge A. Encarnação, Volkmar Wolters

\section{To cite this version:}

Tobias Erik Reiners, Jorge A. Encarnação, Volkmar Wolters. An optimized hair trap for non-invasive genetic studies of small cryptic mammals. European Journal of Wildlife Research, 2011, 57 (4), pp.991-995. 10.1007/s10344-011-0543-9 . hal-00697239

\section{HAL Id: hal-00697239 \\ https://hal.science/hal-00697239}

Submitted on 15 May 2012

HAL is a multi-disciplinary open access archive for the deposit and dissemination of scientific research documents, whether they are published or not. The documents may come from teaching and research institutions in France or abroad, or from public or private research centers.
L'archive ouverte pluridisciplinaire $\mathbf{H A L}$, est destinée au dépôt et à la diffusion de documents scientifiques de niveau recherche, publiés ou non, émanant des établissements d'enseignement et de recherche français ou étrangers, des laboratoires publics ou privés. 


\title{
An optimized hair trap for non-invasive genetic studies of small cryptic mammals
}

\author{
Tobias Erik Reiners • Jorge A. Encarnação • \\ Volkmar Wolters
}

Received: 18 November 2010 /Revised: 26 April 2011 /Accepted: 2 May 2011 /Published online: 15 May 2011

(C) Springer-Verlag 2011

\begin{abstract}
As sample quality and quantity is a crucial factor in non-invasive genetics, we focused on the improvement of sampling efficiency of glue hair traps. We invented an optimized hair trap with moveable parts which enhanced sampling of high-quality genetic material. With the aid of the optimized hair trap, we were able to remotely pluck a sufficient amount of hair bulbs from our study animal the common hamster (Cricetus cricetus) with a trapping success of $49.3 \%$ after one survey night. The number of collected hairs with bulbs ranged between 1 and 50, with an average of $20.7 \pm 14.8$. Subsequently, the use of the hair trap in combination with a simplified laboratory routine allowed us to amplify species-specific microsatellites with an amplification success of $96.2 \%$ and ADO of $4.6 \%$. This optimized trap may find usage for species identification or could be used as an instrument for long-term genetic monitoring of mammal populations.
\end{abstract}

Keywords Cricetus cricetus - Remote collecting · Microsatellites · Non-invasive genetic sampling

Communicated by C. Gortázar

T. E. Reiners $(\bowtie) \cdot$ J. A. Encarnação

Department of Animal Ecology, Mammalian Ecology Group, Justus-Liebig-University of Giessen,

Heinrich-Buff-Ring 26,

35392 Giessen, Germany

e-mail: tobias.reiners@bio.uni-giessen.de

V. Wolters

Department of Animal Ecology,

Justus-Liebig-University of Giessen,

Heinrich-Buff-Ring 26,

35392 Giessen, Germany

\section{Introduction}

Non-invasive sampling techniques for genetic studies on mammals become increasingly important due to ethical, logistical, and scientific restrictions. Those methods allow researchers to collect samples without any observer bias or negative consequences for individuals due to handling or stress. Therefore, they are most frequently applied in studies with rare, cryptic, or endangered species (Piggott and Taylor 2003; Waits and Paetkau 2005). The source of sample material together with DNA extraction methods and PCR conditions is among the most crucial sources of error (Beja Pereira et al. 2009; Broquet et al. 2007; Taberlet et al. 1999). Hair samples are a widely used, non-lethal source of DNA, and recent advantages in molecular techniques provide reliable results through the application of strict guidelines and high-performance analysis techniques (Beja Pereira et al. 2009; Mullins et al. 2009). In contrast, very little attention is directed towards the invention, construction, and application of effective traps that facilitate the collection of high-quality sample material. When using hairs, in particular their bulbs, as a source for DNA, these are needed in sufficient amounts containing enough follicular tissue. A minimum of three to ten hair bulbs are needed to reduce genotyping errors significantly (Gagneux et al. 1997). The use of hair traps with mechanical devices (e.g., barbwire) or attached glue-like substances to collect plucked hairs is not ideal as it rarely collects high proportions of hairs with roots (Ebert et al. 2010; Valderrama et al. 1999). Here, we present a new, costefficient, optimized hair trap for non-invasive sampling that uses movable parts to collect efficiently hairs with 
bulbs. We tested the effectiveness for non-invasive genetic studies by quantifying the amount of hair bulbs, microsatellite amplification success, and genotyping error rates in the endangered common hamster Cricetus cricetus L., 1758.

\section{Materials and methods}

\section{Study area}

This study was conducted between July and September 2009 in Hesse (Germany). In three different study areas, 223 ha of arable fields were surveyed for the presence of common hamster burrows.

\section{Hair trap}

The hair trap is built out of a 5-cm-long PVC pipe with a diameter of $7.5 \mathrm{~cm}$ to match the average diameter of common hamster burrows. Through two holes at the upper periphery of the pipe, a $7.5-\mathrm{cm}$-long steel nail is placed. For trapping hairs, a plastic roll with a diameter of $1.2 \mathrm{~cm}$ was attached using the nail as axis, and double-faced adhesive tape was then wrapped around the roll (Fig. 1a and b). When animals went through the pipe, the plastic roll with the adhesive tape rotates which then results in a vertical extraction of hairs. Hair traps were placed in burrow entrances in the late afternoon and surveyed for hairs early in the next morning (Fig. 1c and d). For each applied trap, the amount of hairs was documented (Fig. 1e and f).

\section{Sample storage}

The appropriate storage and preservation of non-invasive samples is crucial (Beja Pereira et al. 2009). As DNA comes in small quantities and low quality, it should be protected against heat stress or sunlight (Taberlet et al. 1999). As freezing and refrigeration result in physical stress, we used dry preservation. We stored samples in $125-\mathrm{ml}$ vials with $5.5-\mathrm{cm}$ height and airtight closure (Sarstaedt ${ }^{\mathbb{R}}$ ). To dry samples, we attached two packages of Silica Gel (Wisepac ${ }^{\circledR}$ ) to each vial. After successful application in the field, the whole glue-plastic roll was moved to a vial.

\section{DNA isolation and genetic analyses}

DNA extraction was performed using 20\% Chelex following standard protocols (Walsh et al. 1991). This method is used in several other studies with small-sized mammals (Sloane et al. 2000; Moncrief et al. 2008). The roots of ten
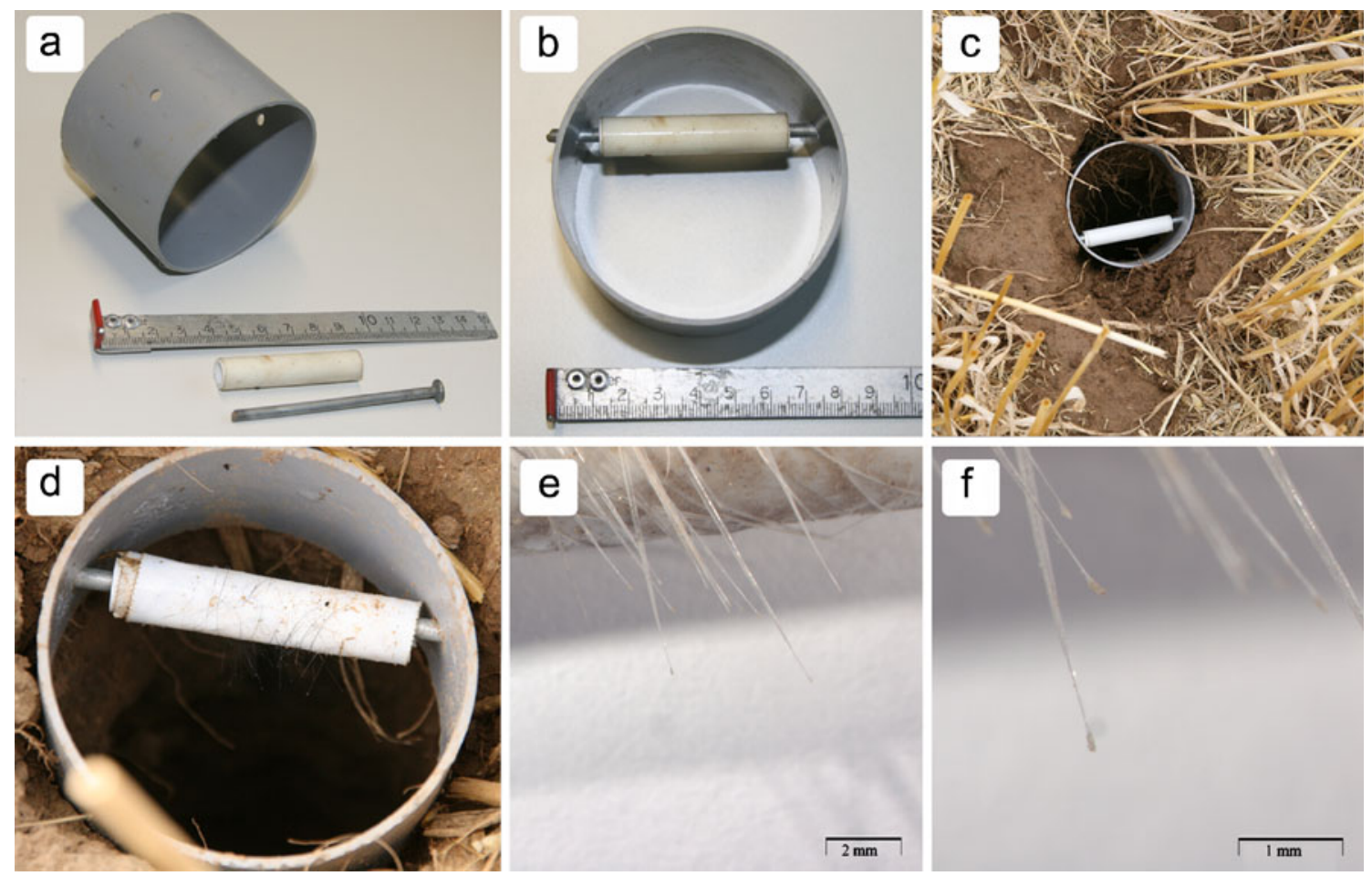

Fig. 1 Materials and application of the optimized hair trap. The trap consists of a PVC pipe with two holes, an iron nail, and a plastic roll (a). The plastic roll is wrapped with double-faced adhesive tape and attached inside the pipe by the nail (b). Traps are placed in entrances of burrows (c), and as an animal passes, hairs are plucked by the rolling tape (d). Most of plucked hair contained bulbs with a sufficient amount of follicular tissue (e and $\mathbf{f}$ ) 


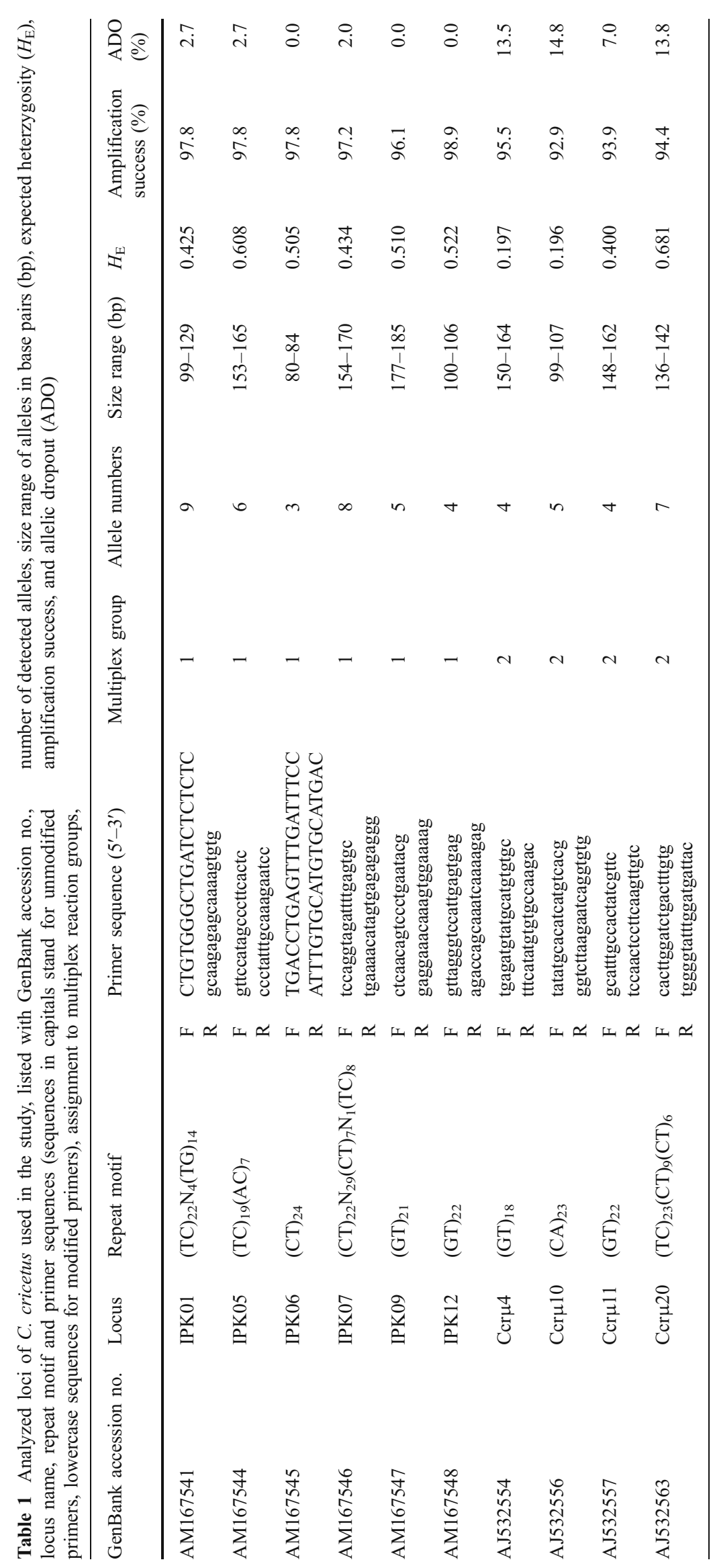


hairs were incubated in $200 \mu \mathrm{l}$ of a $20 \%$ Chelex solution for $2 \mathrm{~h}$. To test if extracts are sufficient for genetic studies, ten species-specific microsatellites were used (Jakob and Mammen 2006; Neumann and Jansman 2004). Primers were modified, respectively new designed, following the guidelines for non-invasive sampling (Broquet et al. 2007; Taberlet et al. 1999) (Table 1). For PCR, the Qiagen ${ }^{\circledR}$ Multiplex PCR Kit was used, arranging primers into two multiplex reactions (Table 1). All reactions were carried out in a separate laboratory with an Eppendorf ${ }^{\circledR}$ MasterCycler Gradient using a $10-\mu 1$ reaction volume with $5 \mu \mathrm{l} 2 \times$ QIAGEN ${ }^{\circledR}$ Multiplex PCR Master Mix combined with the touchdown-PCR technique to increase annealing specificity (Hecker and Roux 1996).

Assessment of amplification success and error rates

Amplification success was measured by counting the amount of failed amplifications for each locus. To test for allelic dropout (ADO), reactions $(n=77)$ and isolations $(n=$ 41) were repeated randomly. ADO was calculated using the equation presented in Broquet and Petit (2004).

\section{Results}

During the study, we applied 199 hair traps to common hamster burrows. At 144 burrows, the trap contained hairs in 98 cases resulting in a $49.3 \%$ trapping success after one survey night. The number of collected hairs with bulbs per trap was between 1 and 50, with an average of $20.7 \pm 14.8(n=98)$ bulbs. The proportion of successful amplifications for the speciesspecific microsatellites over all loci was $96.2 \%$. The rate of ADO over all loci was $4.6 \%$ (Table 1). False alleles were not detected in the dataset. Our approach provided enough material to successfully genotype 88 different individuals.

\section{Discussion}

Recent developments in molecular techniques and genotyping pronounce the importance of non-invasive sampling (Waits and Paetkau 2005). But most non-invasive techniques are still expensive, because reliable and replicated samples of genetic material are only available using costly methods (Navidi et al. 1992). With our approach, we will reduce costs significantly by improving a basal technique for non-invasive genetic sampling. Our study showed that the newly developed trap is easy to apply and provides a high gain of genetic material. Additionally, the glue-containing part is fast and easily replaceable, and samples can be directly conserved for further analyses.
One of the major drawbacks of non-invasive sampling, the generally small amount and low quality of genetic material (Piggott and Taylor 2003), has been overcome by our current approach. As demonstrated, we were able to amplify species-specific microsatellites with high amplification success $(96.2 \%)$ and comparably low error rate (ADO, 4.6\%). These rates are markedly better than the mean amplification success of $80.2 \%$ and mean allelic dropout rate of $18.7 \%$ reported from a review of noninvasive studies using hair samples as source for genetic material (Broquet et al. 2007).

The effectiveness of the hair trap with the glue roll was only shown for one burrow-using species. Our approach may also find use in studies with other species as comparable studies using tubes for species identification without genetic sampling were already conducted (Mortelliti and Boitani 2008; Ruiz-Gonzalez et al. 2008; Sanecki and Green 2005). As a conclusion, this trap is well suited for short- and long-term monitoring studies in population genetics of small mammals and provides a suitable technique for highly replicated studies on relevant, large spatial scales.

\section{References}

Beja Pereira A, Oliveira R, Alves PC, Schwartz MK, Luikart G (2009) Advancing ecological understandings through technological transformations in noninvasive genetics. Mol Ecol Resour 9 (5):1279-1301

Broquet T, Petit E (2004) Quantifying genotyping errors in noninvasive population genetics. Mol Ecol 13(11):3601-3608

Broquet T, Ménard N, Petit E (2007) Noninvasive population genetics: a review of sample source, diet, fragment length and microsatellite motif effects on amplification success and genotyping error rates. Conserv Genet 8(1):249-260

Ebert C, Huckschlag D, Schulz HK, Hohmann U (2010) Can hair traps sample wild boar (Sus scrofa) randomly for the purpose of non-invasive population estimation? Eur J Wildl Res 56(4):583590

Gagneux P, Boesch C, Woodruff DS (1997) Microsatellite scoring errors associated with noninvasive genotyping based on nuclear DNA amplified from shed hair. Mol Ecol 6(9):861-868

Hecker KH, Roux KH (1996) High and low annealing temperatures increase both specificity and yield in touchdown and stepdown PCR. Biotechniques 20(3):478-485

Jakob SS, Mammen K (2006) Eight new polymorphic microsatellite loci for genetic analyses in the endangered common hamster (Cricetus cricetus L.). Mol Ecol Notes 6(2):511-513

Moncrief ND, Van den Bussche RA, Dueser RD, Loftis D, Cockett NE, Culver M (2008) Diagnostic genetic marker that differentiates eastern fox squirrels from eastern gray squirrels. J Wildl Manage 72(1):320-323

Mortelliti A, Boitani L (2008) Inferring red squirrel (Sciurus vulgaris) absence with hair tubes surveys: a sampling protocol. Eur J Wildl Res 54(2):353-356

Mullins J, Statham M, Roche T, Turner P, O'Reilly C (2009) Remotely plucked hair genotyping: a reliable and non-invasive 
method for censusing pine marten (Martes martes, L. 1758) populations. Eur J Wildl Res 56(3):443-453

Navidi W, Arnheim N, Waterman MS (1992) A multiple-tubes approach for accurate genotyping of very small DNA samples by using PCR-statistical considerations. Am J Hum Genet 50 (2):347-359

Neumann K, Jansman H (2004) Polymorphic microsatellites for the analysis of endangered common hamster populations (Cricetus cricetus L.). Conserv Genet 5(1):127-130

Piggott MP, Taylor AC (2003) Remote collection of animal DNA and its applications in conservation management and understanding the population biology of rare and cryptic species. Wildl Res 30 (1):1-13

Ruiz-Gonzalez A, Rubines J, Berdion O, Gomez-Moliner BJ (2008) A non-invasive genetic method to identify the sympatric mustelids pine marten (Martes martes) and stone marten (Martes foina): preliminary distribution survey on the northern Iberian Peninsula. Eur J Wildl Res 54(2):253-261
Sanecki GM, Green K (2005) A technique for using hair tubes beneath the snowpack to detect winter-active small mammals in the subnivean space. Eur J Wildl Res 51(1):41-47

Sloane MA, Sunnucks P, Alpers D, Beheregaray LB, Taylor AC (2000) Highly reliable genetic identification of individual northern hairy-nosed wombats from single remotely collected hairs: a feasible censusing method. Mol Ecol 9(9):1233-1240

Taberlet P, Waits LP, Luikart G (1999) Nonivasive genetic sampling: look before you leap. Trends Ecol Evol 14(8):323-327

Valderrama X, Karesh WB, Wildman DE, Melnick DJ (1999) Noninvasive methods for collecting fresh hair tissue. Mol Ecol 8(10): 1749-1750

Waits LP, Paetkau D (2005) Noninvasive genetic sampling tools for wildlife biologists: a review of applications and recommendations for accurate data collection. J Wildl Manage 69(4):1419-1433

Walsh PS, Metzger DA, Higuchi R (1991) Chelex ${ }^{\circledR} 100$ as a medium for simple extraction of DNA for PCR-based typing from forensic material. Biotechniques 10(4):506-513 